\title{
ペロブスカイト型複合酸化物の生成判定エキスパートシステム
}

\author{
藤原佳子・安井至 \\ (東京大学生産技術研究所, 106 東京都港区六本木 7-22-1)
}

\section{A Trial to Construct an Expert System for the Formation of Perovskite-Type Mixed Oxides}

\author{
Yoshiko FUJIWARA and Itaru YASUI \\ (Institute of Industrial Science, University of Tokyo, 7-22-1, Roppongi, Minato-ku, Tokyo
}

106)

\begin{abstract}
An expert system, which judges what kinds of perovskite-type mixed oxides will be formed in the ternary system of metallic elements, has been constructed as a part of a system for ceramic material design. In this system, formation was judged on the basis of crystallographic knowledge and databases which were collected from the literature: This system has two kinds of databases, all perovskites in the literature and ionic characters of elements. Conditions used to evaluate the stability of perovskites are, (1) charge balance, (2) ionic radius, (3) the stability of each ion and oxygen vacancy in perovskites, (4) stability of each ion of atmosphere, (5) acidbasicity, (6) the properties of d electrons of transition metals.
\end{abstract}

[Received March 15, 1990; Accepted April 13, 1990]

Key-words : Material design, Perovskite-type mixed oxide, Expert system, Database, Formation

\section{1. 緒言}

材料設計とは，「要求仕様を満たす材料の構造 (粒界・ 組織などの高次構造を含む広義の概念でキャラクターと 呼ばれる）を決定し，その構造を持った材料を合成する 最適な方法を示すこと」と定義することができ，このと き, 前者を物性最適化設計, 後者を合成最適化設計と呼 ぶ. 本来, 材料の組成一合成法 $\rightarrow$ 構造 $\rightarrow$ 物性といった四 者の関連付けが行われて初めて, 材料設計が可能になつ たというべきものであるが, 現時点でセラミックスの材 料設計と言えば，構造 $\rightarrow$ 物性を結び付けること，つまり 物性最適化設計を考えるべきである。セラミックス材料 設計支援システムの将来像を図 1 に示す。ここで材料の 物性定数 $a$ をキャラクターの関数として把握するわけ であるが，このときセラミックスのキャラクターのうち 重要なものとして, (1)組成, (2)結晶相, (3)組織, (4)粒界, (5)配向性などを最小限あげることができる。

近年コンピューターそのものの急速な能力の向上と普 及とともに，材料開発のレベルの向上に向けて，コン ピューターに対する期待が大きくなってきた。 セラミッ クスのなかでも溶融法により作製されるガラスについて は，これまでの経験的なルールとデーターベースとを人 工知能 $(\mathrm{AI})$ で組み合わせ，物性を予測するといった エキスパートシステムが構築されている ${ }^{1) ~ 4) . ~ し か し, ~}$ 結晶性のセラミックスの場合には, 組成-物性の関係そ
のものの整理がまだ十分とはいい難く，したがってごく 限られた範囲内でのシステムの試作が行わ机る段階であ る.

ペロブスカイト型複合酸化物 $\mathrm{ABO}_{3}$ は，非常に安定 な構造を有しているため, A サイト又は Bサイトの一部 を他のイオンで置換することにより，混合原子価や酸素

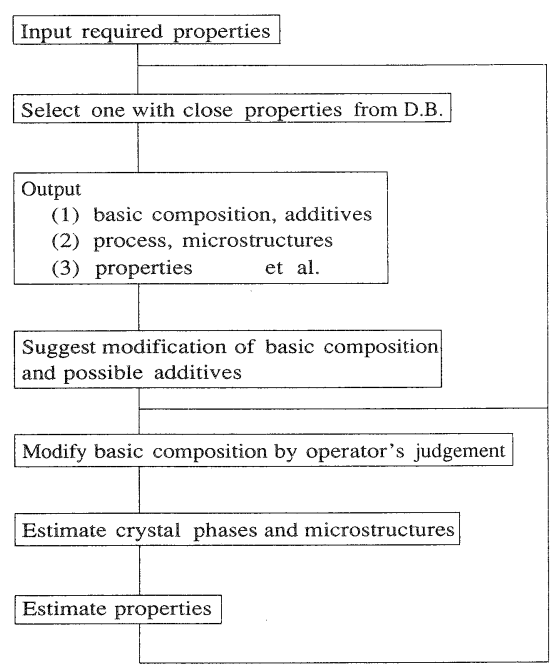

Fig. 1. A flowchart for a ceramic material design system in the future. 
欠陥を容易に発現させることができる ${ }^{51}$. そのため, 電 気的性質, 磁気的性質, 触媒特性について多く研究され てきた。また材料設計という観点から見た場合, 組成を 変化させた場合にも第二相を生成せずに固溶体を形成す る場合には，キャラクターを代表する変数として組成を 採用することが可能である.

そこで, 本研究では, セラミックス材料設計支援シス テムの一部分をなすものとして「任意の金属元素 3 種類 を選択するとその元素を含むいかなるぺロブスカイトが 生成可能か」を判定するエキスパートシステムの構築を 目的亡した。

\section{2. 方 法}

この問題のアプローチの仕方のうち可能なものとし て, イオン半径, 電荷などの知識から推論する結晶化学 的な方法と, 実験データをデータベ一ス化しこれを参照 しながら推論を行うデータベースを活用する方法が考え られる.そこで, このシステムにデータベースとして, 既存のペロブスカイト約 950 種類と, 金属イオンの性質 を持たせた。

一般にこのようなシステムは prolog なよ゙の言語ある いはエキスパートシステム構築用シェルを用いて作られ るが, 今回のシステムのように, 数值演算が比較的多い ものにはこれらは適さない。そこで今回のシステムは, Quick Basic Ver.4.5を用いて作製した.この言語は, プログラムの構造化が可能で，編集と実行を同時に行う ことができ，更に文字列と数值の両方を簡単に取り扱う ことができるため，このようなシステムを作製するのに 非常に適していた。

\section{3. システムの構成}

\section{1 データベース}

このシステムは, 大きく分けて 2 種類のデータベース を持っている。一つは，既存のペロブスカイトに関する もので，もう一つは，イオンの性質に関するものである. 以下それぞれについて述べる.

\section{1 .1 既存のペロブスカイト}

Galasso はペロブスカイト構造をとると報告されてい る物質のリストを作成した帛．極めて多くの物質名が記 載されている. Subbarao は1973 年に強誘電性又は反 強誘電性をもつペロブスカイト型化合物として報告され た物質名リストを発表したが, 過半数の物質について信 憑性のないものであるという判定を示している7 . 物性 のデー夕集である Landolt-Börstein ${ }^{8) \sim 10)}$ に記載されて いる化合物は，その多くが複数の論文の裏付けを得てお り信頼性があると思わ杍. そこで本研究では, 既存の ペロブスカイトのデータは Landolt-Börstein からとり, 最近のものについては, 複数の文献で述べられているも
のについて取り上げることとした。またわかっているも のについては,結晶系についてもデータとして持たせた。

記載されているペロブスカイトは約 950 種類にものぼ るので，検索しやすいようにそれぞれのペロブスカイト を構成する金属元素の組をアルファベット順に並べた index-fileを作った。

\section{1 .2 イオンの性質}

ペロブスカイトが生成するか否かを判定するに当たつ て必要な金属イオンの性質を, データベースとして持つ ことは必須である。そこで以下の性質を各々の金属イ才 ンの価数，配位数によって適宜に定めた。

(1) イオン半径

イオン結晶性の化合物では各イオンを球として近似す ることがよく行われる。しかもそれぞれのイオンは固有 の大きさを持ち，結合する相手が変わってもその大きさ はあまり変化しないと仮定して, イオン半径と呼ばれる ものを求めることが古くから行われてきた．既に 1920 年代に Goldschmidt や Pauling によって現在でも十分 通用するような值が求められている。 そののち Ahrens によって精密化され ${ }^{11)}$, Shannon によって更に精密化 された ${ }^{12)}$. 提案されているこれらのイオン半径は少しず つ異なり，よ゙の值を使うべきか判断に苦しむ場合がある。 Shannon のデー夕は比較的新しいものではあるが，か なり特殊な結晶構造についても当てはまるように值が定 められているので，簡単な構造あるいは対称性の高い構 造については必ずしもよい一致を与えないといわれてい る.そこで本研究では, Ahrens の求めたイオン半径を 用いることとした。6配位位置におけるイオン半径は Ahrens の值そのものでよいが，12配位位置におけるイ オン半径は, Ahrens の值に補正係数を乗じて近似值を 求めることにした。なお，Ahrens の求めたイオン半径 表に記載されていないものは, 適宜推測し定めた。

（2）イオンの安定性

ペロブスカイトの安定性は, それを構成するイオンの ペロブスカイト中での安定性による，遷移金属の場合， 見掛け上の価数は, 数種類の可能性がある. 本来イオン の安定性を考えるとき, 熱力学的アプローチを試みるわ けである. 気相と単一固相により構成される熱力学的平 衡は相律 $(f=c-p+2)$ から, 自由度 $f=2$ を持つ。 そこでイオンの価数を決定するためには，温度と酸素分 圧を定めなくてはいけない。仮に焼成温度を $1200^{\circ} \mathrm{C}$ 上 定めると

$$
\mathrm{M}^{n+}+\frac{1}{4} \mathrm{O}_{2}=\mathrm{M}^{(n+1)}+\frac{1}{2} \mathrm{O}^{2-}
$$

という平衡を考えて，この自由エネルギーが分かればよ い.しかし, この種の熱力学的デー夕はほとんどない。 したがってここでは既存のペロブスカイトの経験則によ り，各イオンのペロブスカイト中での安定性を，非常に 
安定なものを 1.0 として他は適宜定めた.

(3) 酸素欠陥に関するデー夕

あるぺロブスカイトが酸素欠陥をつくってまでもその 構造を保つか, またはぺロブスカイトの構造を崩してし まうかということは, 各イオンの特性として表すことが できると思われる.例えば, $\mathrm{La}_{3-x} \mathrm{Ln}_{x} \mathrm{Ba}_{3}\left(\mathrm{Cu}_{5-2 y}^{2+} \mathrm{Cu}_{1+2 y}^{3+}\right)$ $\mathrm{O}_{14+y}$ は, かなり多くの酸素欠陥が観察される ${ }^{13)}$. また, $\mathrm{SrCoO}_{3-x}$ でも䨌囲気によってはかなりの酸素欠陥が存 在する ${ }^{14)}$.これは，構成イオンに酸素を取り込む性質が あるかどうかによる。このように金属イオンには酸素欠 陥の存在を許すものと許さないものがあると考え，ある 程度存在を許すものを 0.5 とし, 全く許さないものを 0.1 とし, そのあいだですべてのイオンについて適宜定 めた。

\section{（4）酸一塩基性}

複合酸化物形成及びその安定性において酸化物の酸塩基性は非常に重要である。そこで，Duffy-Ingram の Acidbasicity $^{15)}$ を参考に各イオンの価数, 配位数を考慮 して定めた. Z r の Acidbasicity の值は 1.55 であるが, これを中性とした。なお Duffy-Ingramの值は, Pauling の電気陰性度を基本として定めたものであるが，こ れはガラス中での物理的性質や化学的性質を非常によく 説明できるので，信頼がおけると思われる。

（5）雾囲気制御に関する性質

各イオンが安定であるためには, 酸素雾囲気, 還元雾 用気といった雾囲気制御が必要か否かということを記載 した. 酸素雾囲気中で安定なイオンは+1, 還元雾囲気 中で安定なイオンはー1 とし, 空気中で安定なイオンは 0 とした.

以上のことを記載したデータベースの一例を図 2 に示 ఫ.

\section{2 判断基準}

このシステムのフローチャートを図 3 に示す。まず表 示された周期率表からキーボードを用いて金属元素 3 種 類を選択し，各イオンの性質をデータベースから得る部 分, その 3 元素を含むぺロブスカイトをデータベースか
(1) (2) (3) (4)
(5) (6) (7) (8)
"Fe", 2, 6, 0.74, "B", 39, 3, 0.5, 0.3, 2.09, -1
"Fe", 3, 6, 0.64, "B", 38, 2, $1,0.3,2.23,0$
"Fe", 4, 6, 0.58, "B", 37, 1, 0.1, 0.3, 2.36, 0
"Co", 2, 6, 0.72, "B", 42, 3, $1,0.3,2.09,0$
"Co", 3, 6, 0.63, "B", 41, 2, 0.6, 0.3, 2.23, 0
"Co", 4, 6, 0.57, "B", 40, 1, 0.3, 0.3, 2.36, 1
"Ni", 2, 6, 0.68, "B", 45, 3, $1,0.3,2.09,0$
"Ni", 3, 6, 0.60, "B", 44, 2, 0.3, 0.3, 2.23, 1
"Ni", 4, 6, 0.55, "B", 43, 1, 0.1, 0.3, 2.36, 1

Fig. 2. Examples of ionic characters in the database. (1) atomic name, (2) valence, (3) coordination number, (4) ionic radius, (5) ionic stability, (6) stability of oxygen vacancies in perovskite, (7) acidbasicity, (8) stability in atmosphere
ら検索する部分, そしていかなるペロブスカイトが生成 可能かということを判定するこのシステムのメインの部 分, と大きく三つの部分に分けられる. 以下ペロブスカ イトの作製の仕方，それらの生成に関する判定基準につ いて述べる。

\subsection{1 ペロブスカイトの組成}

選択された金属イオン 3 種類に少なくとも一つ以上 12 配位可能なイオンと 6 配位可能なイオンが存在する 場合, 以下の要領であらゆる組み合わせのペロブスカイ トを作製し生成の判定をすることとした。 $\mathrm{ABO}_{3}$ 型のも のは，Aサイトの価数とBサイトの価数の和が 5.7 から 6.01 の範囲内にあるもののみ作製する。 $\mathrm{A}\left(\mathrm{B}_{x} \mathrm{~B}_{1-x}^{\prime}\right)$ $\mathrm{O}_{3-\sigma}$ 型のものは, $\mathrm{B}$ と $\mathrm{B}^{\prime}$ の価数が違うものについては, $\delta$ の值が 0 と0.25のものについてのみ作製し， Bと $\mathrm{B}^{\prime}$ の価数が同じものについては，もし $\delta$ の值が 0 から 0.25 の範囲で作製可能なものについては， $x$ の值を 0.2 から 0.8 まで 0.2 きざみで作製した. また B と $\mathrm{B}^{\prime}$ が違 う種類の金属で少なくとも一方の金属が混合原子価を作 るものはあらゆる可能性について混合原子価を発現させ た. $\left(\mathrm{A}_{x} \mathrm{~A}_{1-x}^{\prime}\right) \mathrm{BO}_{3-\sigma}$ 型のものも，Bサイト混合の場合

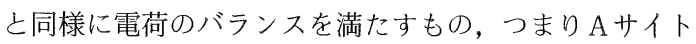
とBサイトの価数の和が 5.5 と 6.0 のもの, 言い換えれ ば $\delta$ の值が 0.25 と0ものを作製した。

\subsection{2 判断基準}

(1) イオン半径 ペロブスカイトの単位格子を考え, Ewaltによって発

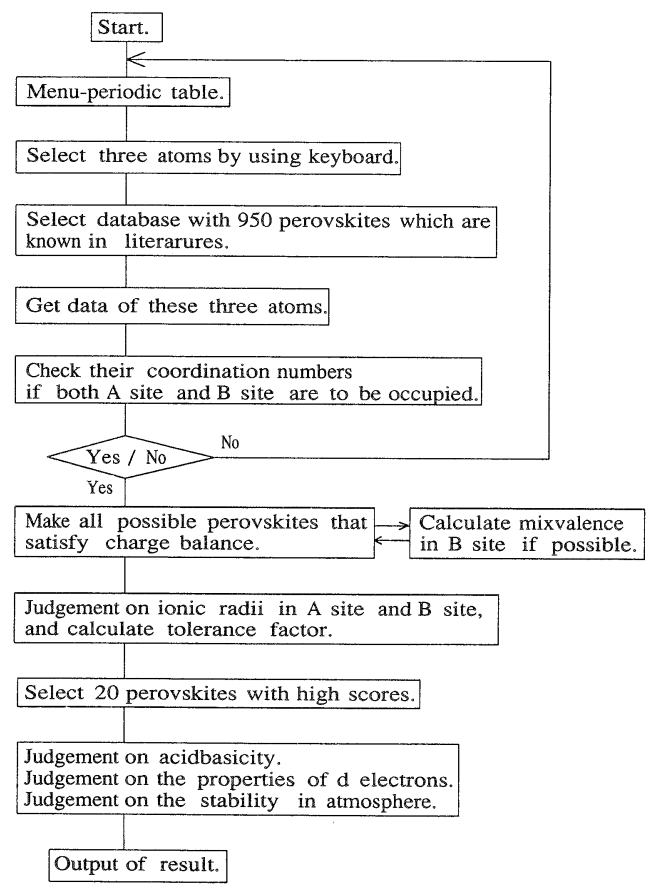

Fig. 3. A flowchart of the expert system for the formation of perovskite-type mixed oxides. 


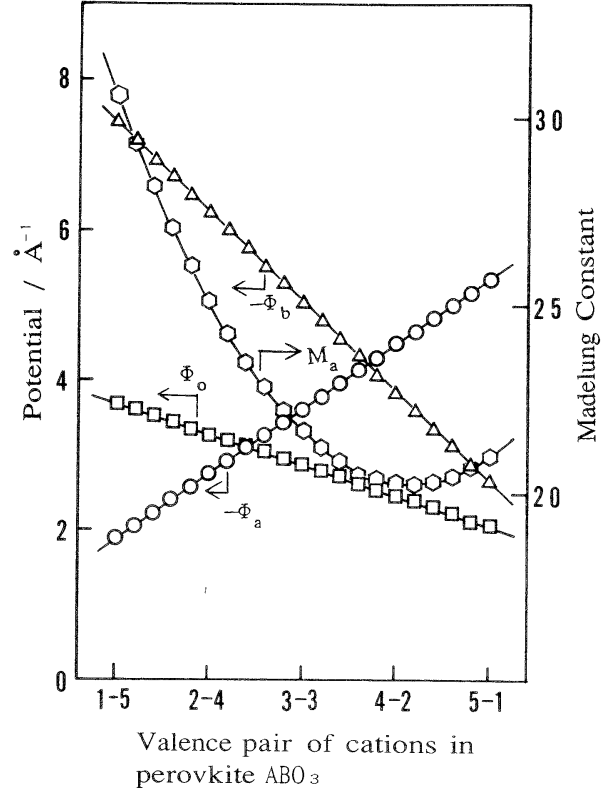

Fig. 4. Effect of valence on lattice self-potential and Madelung constant of perovskite $\mathrm{ABO}_{3}$. Characteristic length, $a$, is taken to be $1.0 \AA$ in all cases. Each ion is assumed to be at an ideal site.

展された計算を速く収束させる簡単な方法により ${ }^{(6)}$ マー デルンク定数を計算した結果を図 4 に示す。A-B イ才 ンの原子価対が 1 価-5 価から 3 価-3 価へと変化するに つれてB位置の格子ポテンシャルが減少し，代わりにA 位置の格子ポテンシャルが増大するとともにマーデルン ク定数は急減した。格子エネルギーは，反発項を無視す ると

$$
U=-N_{\mathrm{e}}{ }^{2}\left(M_{\mathrm{a}} / a_{0}\right)
$$

$M_{\mathrm{a}}$ : マーデルンク定数

$a_{0}$ : 格子定数

と表せるので, 1 価-5 価のペロブスカイトが 3 価-3 価 のそれと同じ格子エネルギーをもつためには，つまり同 じ安定性を持つには，格子定数 $a_{0}$ は大きくてよい，格 子定数は $\mathrm{A}$ サイトイオンの大きさに依存するので, ペロ ブスカイトとなる $\mathrm{A}$ サイトイオン半径の最大值は, 価数 の組み合わせが 3 価-3 価から 1 価-5価になるに従って 大きくするべきである。そこで，既存のペロブスカイト のイオン半径も考慮にいれて $\mathrm{A}, \mathrm{B}$ サイトイオン半径の 範囲を Aサイトイオンの価数の関数として図 5 のように 定めた。

この範囲内にそれぞれのイオン半径がある場合，範囲 の中央点と境界点で区別をつけるため範囲の中央点で 10 点, 中央から離れていくに従って 2 次関数的に点数 が減少するようにしてアナログ的評価を試みた。ここで 得られた $\mathrm{A}$ サイトイオン半径の点数を $p a, \mathrm{~B}$ サイトイ オン半径の点数を $p b$ とする。

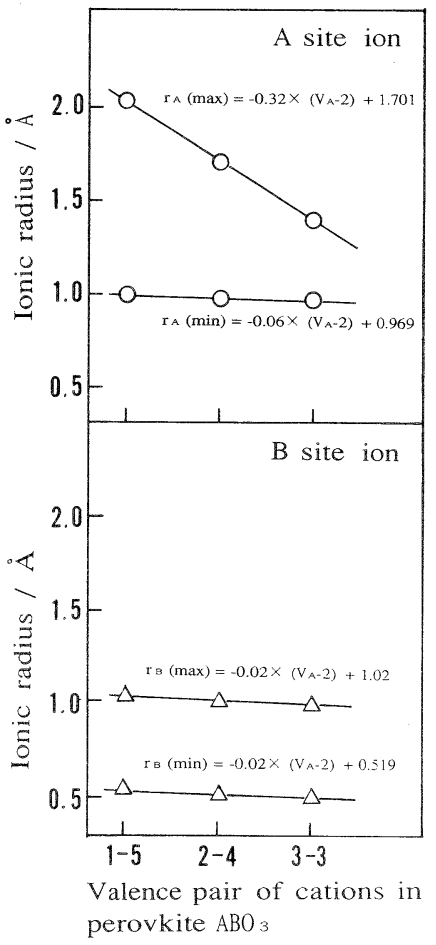

Fig. 5. Boundaries of ion radius for in A site and B site when $\mathrm{ABO}_{3}$ takes perovskite-type structure.

また A，Bイオンの相関性を持たせるために Tolerance Factor を計算し, 表 1 のうに評価し，この点数 を $p c$ とする. 以上イオン半径の総得点を

$$
r \text { point }=p a \times p b \times p c
$$

とする。

（2）イオンの安定性

ペロブスカイトの安定性は, その価数のイオンが安定 か否かに大きく左右さ机る。そ己で構成するすべてのイ オンの安定度を表すファクターを掛け合わせペロブスカ イトのイオンの安定度とした。これをcstabとする。

\section{（3）酸素欠陥の安定性}

ペロブスカイトは, 酸素欠陥が存在しない方が一般的 には安定である。そこで酸素欠陥が存在するものにはぺ ロブスカイトの安定性が損なわれる分のファクタ一を掛 けなければならない。このファクターをcvacantとす

Table 1. Judgement on tolerance factor in this system.

\begin{tabular}{ll}
\hline $\begin{array}{l}\text { Tolerance } \\
\text { Factor }\end{array}$ & $\begin{array}{l}\text { Point } \\
{[\mathrm{PC}]}\end{array}$ \\
\hline $\mathrm{TF}>1.05$ & 0.1 \\
$1.05 \geqq \mathrm{TF}>0.99$ & 0.3 \\
$0.99 \geqq \mathrm{TF}>0.79$ & 1.0 \\
$0.79 \geqq \mathrm{TF}>0.7$ & 0.2 \\
$\mathrm{TF} \geqq 0.7$ & 0.05 \\
\hline
\end{tabular}


る.酸素欠陥の存在しないものは, $c$ vacant $=1.0$ となる. 酸素欠陥の存在するペロブスカイトについては，それ を構成するすべてのイオンの酸素欠宿安定度の平均值を そのペロブスカイトの酸素欠陥の安定度とした。

以上イオン半径, イオンの安定性, 酸素欠陷の安定性 を加味したペロブスカイトの総得点を

$p$ eval $=r$ point $\times c$ stab $\times c$ vacant とした。

$\mathrm{A}\left(\mathrm{B}_{x} \mathrm{~B}_{1-x}^{\prime}\right) \mathrm{O}_{3}$ 系で $\mathrm{B}$ サイトが混合原子価を作るもの については，その中で一番高得点なもののみ採用したう えで，作製したペロブスカイトの中で上位 20 個を選択 し，以下の判定へと進む。

（4）遷移金属に関する判定

$\left(\mathrm{La}_{1-x} \mathrm{Sr}_{x}\right) \mathrm{MO}_{3-\sigma}$ 系については, $\mathrm{M}$ が $\mathrm{Mn}, \mathrm{Fe}, \mathrm{Co}$ の順に高原子価が安定であることが熱天秤を用いた高温 微量重量法に上るノンストイキオメトリ測定によりわ かっている177,18)。これは $\mathrm{Mn}, \mathrm{Fe}, \mathrm{Co} の \mathrm{~d}$ 電子のエネ ルギーに差があるためと考えられる。一方，La $\left(\mathrm{Mn}_{1-x} \mathrm{Co}_{x}\right) \mathrm{O}_{3-\sigma}$ や $\mathrm{La}\left(\mathrm{Fe}_{1-x} \mathrm{Co}_{x}\right) \mathrm{O}_{3-\sigma}$ の上うな $\mathrm{B}$ サ ト混合ペロブスカイトでは $\mathrm{B}$ サイト位置のイオンの価数 の組み合わせはいくつか考えられるが，上記の A サイト 混合系での現象考考合わせると，例えば Mn-Co 系で は $\mathrm{Mn}$ の d 電子が $\mathrm{Co}$ に移り，一部 $\mathrm{Mn}^{4+} \mathrm{Co}^{3+}$ で安定な 電子構造となっていることが考えられる。この $\mathrm{Mn}^{4+} \mathrm{Co}^{3+}$ がノンストイキオメトリの増大にともない電 荷補償をどのようにするかは，非常に興味が持たれる。 この場合 $\mathrm{Mn}^{4+} \mathrm{Co}^{2+}, \mathrm{Mn}^{3+} \mathrm{Co}^{3+}$ の 2 種類が考えられる が，Co の原子価は Mn の原子価と同じかそれより低い と考えるのが妥当と思われる. $\mathrm{Fe}-\mathrm{Co}$ 系についても同 様な議論ができ Fe の d 電子が Co に移っているモデル が考えられる。

そこでこれらの経験則から,第一遷移金属については, 原子番号の小さいものの方が平均原子価が低い場合にか ぎり総得点に 0.1 というファクター $p m$ を掛けること とした。それ以外のときは $p m=1.0$ である。 peval $1=p$ eval $\times p m$

(5) 酸-塩基

酸化物には電子供与体として作用するものと電子受容 体として作用するものがある。前者の例として $\mathrm{Na}_{2} \mathrm{O}$, $\mathrm{CaO}, \mathrm{BaO}$ などがあり, 後者の例として $\mathrm{SO}_{3}, \mathrm{SiO}_{2}$, $\mathrm{TiO}_{2}$ なビがある. 電子供与体の酸化物之電子受容体の 酸化物を一緒にすると結合することが当然期待される. 酸之塩基についての極めて一般的な概念を与えたのは Lewis である. 彼の定義によ机ば，塩基とは電子供与 体として作用する物質いっさいであり，酸は電子受容体 としての作用をする物質のすべてである.

複合酸化物形成及びその安定性を考える場合，酸化物 の酸，塩基性は非常に重要である。ペロブスカイト中で
は，Aサイトは比較的塩基性なもの (Acidbasicity の小 さいもの)，Bサイトは比較的酸性なもの(Acidbasicity

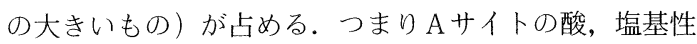
を $\mathrm{po}(\mathrm{A})$ ，Bサイトの酸，塩基性を $\mathrm{po}(\mathrm{B})$ としたとき (以後酸, 塩基性は po で表す) po(B)-po(A) が大き いほど安定であり，この值が 0.07 より小さくてペロブ スカイトが生成することが知られているものはない。ま た特殊な例として，Bサイト混合系で，一方のBサイト イオンが強塩基性のもの（例えば $\mathrm{La}, \mathrm{Ba}, \mathrm{Sr}$ など）で あるとき，B' イオンは特に強酸性のイオンでなくては ならない。更にBサイトイオンの酸性度が強いほどペロ ブスカイトは安定である。

以上のことから，ペロブスカイトの $\mathrm{A}$ サイト， $\mathrm{A}^{\prime} サ$ イト，Bサイト， B'サイトのAcidbasicity を計算して， その值を根拠にした各々のペロブスカイトの安定度を表 すファクター $p w$ を定め,

$$
\text { peval } 2=\text { peval } 1 \times p w
$$

とした.

\section{（6）雾囲気制御}

各サイトのイオンの価数は，調製時の酸素分圧に大き く依存する。乞こで酸素雾囲気中, 空気中, 還元雾囲気 中でそのペロブスカイトが安定か否かは，構成イオンの それぞれの雲囲気中での安定性で決まると仮定して判断 した，構成するイオンに酸素雾囲気中で安定なイオンと 還元需囲気中で安定なイオンが共存する場合, そのペロ ブスカイトは不安定と思われるのでファクターを $p i=$ 0.1 とした。共存しない場合は, 空気中で安定なイオン の種類の数を N 1 , 䨌囲気制御が必要なイオンの種類の 数を $\mathrm{N} 2$ としたとき

$$
p i=\left(1 \times \mathrm{N}_{1}+0.5 \times \mathrm{N}_{2}\right) /\left(\mathrm{N}_{1}+\mathrm{N}_{2}\right)
$$
とした.

このように雾囲気制御に関するファクター $p i$ を定め peval $3=$ peval $2 \times p i$

とした.

すべての判断を終了したとき各々のペロブスカイトの 安定度を示す尺度は peval 3 である。 そこで上位 20 個 のペロブスカイトを安定な順に並べかえ結果を表示す る.

\section{4. システムの実行例及び考察}

\section{1 La, Sr, Co を選択した場合}

図 6 (a) に判定結果を示す。2成分系からなるペロブ スカイトでは $\mathrm{LaCoO}_{3}, \mathrm{SrCoO}_{3}$ が非常に生成しやすく 特に $\mathrm{LaCoO}_{3}$ では $\mathrm{Co}$ の価数は, 2 価-3 価, 2 価 -4 価の 混合原子価よりも 3 価単独で存在するものの方が安定で あることがわかった。また $\mathrm{LaCoO}_{3}$ の $\mathrm{La}$ の一部を $\mathrm{Sr}$ で置換していく系 $\left(\mathrm{La}_{1-x} \mathrm{Sr}_{x}\right) \mathrm{CoO}_{3}$ については $x=0.6$ までは生成しやすいが，0.8になるとほとんど生成する 
ce and Technology, 7, Elsevier (1984) p. 83.

16）C. Kittel, “固体物理学入門”, 付録 A, (昭和 33 年).

17) J. Mizusaki, M. Yoshihiro, S. Yamauchi and K. Fueki, J. Solid State Chem., 58, 257 (1985).
18）下山淳一, 修士論文 (東京大学工学部, 1988).

19) R. R. Kreiser and R. Ward, J. Solid State Chem., 1, 368 (1970). 